\title{
Study on the Relationship between the Backgrounds of Top Managers and Organizational Performance
}

\author{
Lilong Liu, Qianqian Guo \\ Xiamen University of Technology, Xiamen, Fujian, China
}

\begin{abstract}
Keywords: Rent-seeking Theory; Resource-dependence Theory; Organizational Performance; Backgrounds of Top Management
\end{abstract}

\begin{abstract}
Top Managers are an important human resource that controls the company's operations, the research of top managers' background becomes an important issue in corporate governance. Based on the theory of rent-seeking and the theory of resource dependence, this paper studied on relationship between the backgrounds of top managers and organizational performance. The research conclusion of this paper provides useful thoughts for the company to making corporate governance strategy, and provides the idea for the company to select top management personnel.
\end{abstract}

\section{Introduction}

In the context of China's economic transformation and institutional transformation of the dual transition period of the background. China's private firms in the development, more attention to the relationship between business and government. In modern private firms, the role of political connections gradually valued. It has a political background of private business executives are increasing; political affiliation important position in private firms has become increasingly prominent.

\section{Literature review}

The important background of top managers is their political connection. A large number of literature studies show that political connections can bring benefits to companies, such as better bank loans and lower tax rates, more government bailouts, bigger market share and more government subsidies (Ma Xiaowei etc., 2010). In the process of measuring and defining political connections, Roberts (1990) argues that politics refers to the relationship between the firm and the politicians. Faccio (2010) argues that more than $10 \%$ of the company's largest shareholders or executives are members of Congress, ministers, government leaders, or close to government officials, and then the company can think of establishing a political connection [1].

So far, foreign scholars in the study of political connection, more to take into account the political connection on the business aspects of the impact of trying to establish a political point of view from different perspectives to explain. Rajan, Zingales (1998) argues that in the case of corruption and inefficiency in Asian economies, contract execution is declining, capital scarcity, and political connection as an alternative to corruption and inefficient relations based on the Asian economy System play a role. Power relations replace contracts, to achieve better results than the original contract system [2-4].

Fisman (2001) shows that the political connection of firms can determine most of the firm value, political connections are clearly important; corruption is an explanation of the establishment of political connection between firms, political connection may play an important role in many important economies [4].

To explain the impact of political connections on credit access, the role of financial development, and the relationship between them, Lashitew (2014) studied the analysis of data based on a manufacturing firm that covers dozens of developing and transition countries; The conclusion of the study of the time spent by senior managers and government officials shows that the stronger the political connection, the more significant positive effect on credit access [5].

In addition, political connections are also affected by the degree of market competition. Faccio (2017), by studying the mobile telecommunications industry, has seen a greater degree of market 
competition in a more democratic country, in Scandinavia, while controlling market size differences, while in areas where market competition is low Mobile operators have more political connection, political power can affect the degree of competition [6].

The establishment of political connection allows companies to enjoy the benefits of policy tilt. Faccio (2017) argues that most democratic governments tend to design more competitive rules, and that more operators with political affiliates can distort rules and make rules favorable to them and restrict competition. Government intervention has a large redistribution effect [7].

\section{Theoretical analysis and research hypothesis}

\subsection{Theoretical analysis}

The theoretical basis of this paper comes from two theories:

First, rent-seeking theory. Buchanan (1980) argues that rent-seeking refers to a background behavior system in which individuals maximize the value through social waste but do not generate social surplus. People use the privileges of government connections to seek benefits, and their benefits are less than the loss of the interests of others. To compete with the state-owned firms, through rentseeking to get more social market resources. In order to win, private firms in the rent, hire executives with government background to obtain political privileges or alliance with the government. After establishing political connection, firms enjoy the benefits of policies or systems through government privileges, but their policies or systems may bring losses to other firms and unbalanced the allocation of social resources.

Second, the theory of resource dependence. The assumption of resource dependence theory is that any organization is not independent of the existence of the organization to survive, the need to exchange resources with the external environment. If an organization has an irreplaceable resource of scarcity and importance, and then when another organization produces demand, the demand side will have a strong dependency on the controlling party. To extend the survival time, the organization can choose to take some measures to reduce dependency, while finding a long-term use of the organization, a solid important access to resources. Private firms through government participation in government approval, or the appointment of officials to establish a good communication channels to maintain the relationship between government and firms, thereby reducing the dependence of private firms on the government.

\subsection{Research hypothesis}

Based on the theory of rent-seeking and resource dependence, this paper finds out that political connection can bring the political privilege and social resources needed for the firm. In addition, domestic and foreign scholars through research to draw the same conclusion, that is, firms pay a certain price, through some way to establish political connection, can help firms to survive and operate. According to $\mathrm{Wu}$ Jingjie (2016), it is concluded that the maintenance of the business environment requires the establishment of political connection, and political connection play an important role in the maintenance. Fisman (2001) research shows that the political connection of firms can determine the majority of corporate value; political link is clearly very important [8].

In China's socialist market economy, the establishment of political connections, private firms can mainly get two benefits, political privileges and social resources, and government officials can rent for the power. After establishing a political connection, the government gains political privileges and is able to take care more in policy than other private firms. Private firms will enjoy more in the market of production factors and social resources. Private firms in access to political privileges and social resources can effectively reduce the dependence of private firms on the government, so that firms can be more stable and long-term development.

In addition, private firms with political connection can rely on political privileges to negotiate with the government to reduce the difficulty of solving these threshold problems and preferential problems in the process of entering the control industry, financing problems, tax relief or subsidy. The government can maximize the benefits of power and achieve policy objectives [9]. 
However, government officials in the process of rent seeking their own, the individual benefits of their own is less than the political connection and the interests of private firms to other firms caused losses. At the same time, firms in order to maintain political connections, whether the economic costs paid with the benefits of the relative to be studied.

Based on the above analysis, this paper presents the following assumptions:

Assuming 1a. The private firms whose top managers with the background of political connections have better organizational performance.

Assumptions 1b. To maintain political connections, private firms has to pay a higher cost, the private firms whose top managers with the background of political connections have worse organizational performance.

Assuming 1c. The private firms whose top managers with the background of political connections are not related to firm performance.

$\mathrm{Yu}$ Mingguo etc.(2010) that the poor institutional environment in the region, the establishment of political connections will receive more government subsidies, the institutional environment is worse, the higher the subsidy should be. In areas with good institutional environment, it is more difficult for governments to intervene less, have a high degree of marketization, many firms, highly competitive firms with political connections, and have real influence of political privileges or gain real economic benefits. So once these areas of firms to obtain political rights, and the success of the actual economic benefits, will improve the performance of firms.

After summarizing the previous analysis, this paper presents the following assumptions:

Assumptions 2. The areas which regional institutional environment is good and the government intervenes is weak, top managers with the background of political connections will improve organizational performance.

At present, Chinese scholars use the dummy variable method, the proportional method and the point method to measure the degree of political connection in the related research of political connection and firm performance. Rijkers et al. (2015) explain the dummy variable method: if the company's executives have or have a political experience, the dummy variable is taken as 1 , otherwise it is 0 . The dummy variable method uses a delegate to establish a political connection, and 0 represents no political relationship. Proportion refers to the proportion of executives who calculate the number of executives who have established political relations. Agrawal et al. (2001) use the proportion of corporate executives or shareholders with political backgrounds to measure the strength of corporate political connection. Point law refers to the establishment of political connection. Hu Xuyang (2006) assigns a score of 0 to 5 from the identity of the delegate class, and gives the square result of the political connection. This paper follows the dummy variable method that Chinese scholars use in the study of political connection, and measure the political performance of private firms.

In addition, this paper chooses the return on assets (ROA) and return on net assets (ROE) as a measure of corporate performance variables. This paper also uses the Chinese marketization index to measure the institutional environment of each region as a new control variable. This article takes the industry classification guidelines of China Securities Regulatory Commission as a reference, divides the classification of Chinese private listed companies, and distinguishes whether the company is the control industry.

\section{Research design}

\subsection{Models and variables}

Based on the hypothesis, the political connection has a significant positive correlation with the performance of the firm. This paper designs the following multiple linear regression model for empirical research:

$\mathrm{ROA}=\alpha+\beta_{1} \mathrm{PC}+\beta_{2}$ Province $+\beta_{3} \mathrm{PC} *$ Province $+\beta_{4}$ Industry $+\beta_{5}$ Size $+\beta_{6} \mathrm{D} / \mathrm{S}+\beta_{7} \mathrm{LEV}+$

$\beta_{8}$ Year $+\varepsilon$

$\mathrm{ROE}=\alpha+\beta_{1} \mathrm{PC}+\beta_{2}$ Province $+\beta_{3} \mathrm{PC} *$ Province $+\beta_{4}$ Industry $+\beta_{5}$ Size $+\beta_{6} \mathrm{D} / \mathrm{S}+\beta_{7} \mathrm{LEV}+$

$\beta_{8}$ Year $+\varepsilon$ 
The above model is used to test this hypothesis that political connection have a significant positive correlation to firm performance. The model of PC* province is the cross of the political system and the regional institutional environment. If the cross factor $\beta_{3}$ is significantly greater than 0 , the establishment of political connections in the favorable environment of the regional system will bring economic benefits or political privileges to the private firms. Policy bias or increase the feasibility of government subsidies; if significantly less than 0 , indicating that in a good regional institutional environment, the establishment of political connections will damage the economic interests of private firms; if $\beta_{3}$ is not significant, can be considered no significantly relationship between the two.

The variables required for the above model are described below.

The backgrounds of top management (abbreviated as PC)

In this paper, we focus on the political connection backgrounds of top management, the use of dummy variable method to identify the independent political connection, that is, with a representative of the establishment of a political connection, 0 represents no political connection. This article will meet the senior management team members or the following positions as a condition to determine the private firms. Political connection standards, including the central government, local government officials, deputies at all levels, CPPCC members. If the above conditions are met, the political connection is identified as 1 , otherwise 0 .

Business performance (ROA, ROE)

Chen Xiaojiao (2016), Shao Shuai (2015) in the study of private firm performance, the use of return on assets (ROA), net assets yield (ROE) to measure business performance. Therefore, based on the previous research, this paper uses the three indexes of return on assets (ROA) and return on net assets (ROE) as a measure of corporate performance, and a comprehensive and effective measure of corporate performance.

Regional institutional environment (Province)

Based on the research results of Fan Gang, Wang Xiaoru and Zhu Hengpeng (2011), the 2011 Annual Report on the Relative Process of Marketization of Provinces and Regions in China Provided by the Ministry of Foreign Trade and Industry, and the extent to which the provinces, autonomous regions and municipalities directly under the central government were intervened by the government, Institutional Environment Index.

Regulatory Industry (Industry)

The regulatory industry classification of private enterprises in this paper is based on the guidance on industry classification of listed companies issued by CSRC in 2012, among which: agriculture, forestry, animal husbandry and fishery (A), mining (B), manufacturing (C), electricity, heat, power, industry, and so on. In this paper, the classification of listed companies, Gas and water production and supply (D), construction (E), information transmission, software and information technology services (I), real estate $(\mathrm{K})$ for the government strict control industry, Industry logo is 1 , other industries are marked Is 0 .

Other control variables (Size, D / S, LEV, Year)

Finally, this paper refers to other scholars' research, adding other control variables such as firm size, debt sales ratio (D / S), asset liability ratio (LEV), time (Year).

\subsection{Data source and description}

This data sample for the 2010-2015 listed in China's Chinese private firms. This paper mainly collects firm financial data from CSMAR database, and collects data of institutional environment from Fan Gang et al. (2011) China's market-oriented index system, using SPSS 22.0 software to analysis [10]. In addition, this article, according to the company's annual report, through manual collection and computer-aided, to supplement the management of political connection. The final sample of the total 5084, by 1360 private firms (Table 1 ). 
Table 1 Empirical Study Variable Set Table

\begin{tabular}{|c|c|c|}
\hline $\begin{array}{l}\text { Variable } \\
\text { type }\end{array}$ & Variable name & Definition \\
\hline $\begin{array}{c}\text { Explanatory } \\
\text { variables }\end{array}$ & $\begin{array}{l}\text { Backgrounds of } \\
\text { top management } \\
\quad(\mathrm{PC})\end{array}$ & $\begin{array}{l}\text { Whether the executive team of a private firm has a political } \\
\text { relationship with a government official or a member. } \\
\qquad \begin{array}{l}1=\text { firms with political connections, } \\
0=\text { firms do not have the political connections }\end{array}\end{array}$ \\
\hline \multirow{2}{*}{$\begin{array}{l}\text { Explained } \\
\text { variable }\end{array}$} & ROA & net profit / total assets $\times 100 \%$ \\
\hline & ROE & net profit / average shareholders' equity $\times 100 \%$ \\
\hline \multirow{6}{*}{$\begin{array}{l}\text { Control } \\
\text { variable }\end{array}$} & $\begin{array}{l}\text { Regional } \\
\text { institutional } \\
\text { environment } \\
\text { (Province) }\end{array}$ & $\begin{array}{l}1=\text { The regional index of the firm is greater than the national } \\
\text { average, the regional institutional environment is good, } \\
0=\text { The regional index of the firm is less than the national } \\
\text { average and the regional institutional environment is poor }\end{array}$ \\
\hline & $\begin{array}{c}\text { Regulatory } \\
\text { Industry(Industry) }\end{array}$ & $1=$ regulatory Industry, $0=$ not regulatory Industry \\
\hline & $\begin{array}{c}\text { Enterprise size } \\
\text { (Size) }\end{array}$ & Enterprise size $=\log _{10}$ assets \\
\hline & $\begin{array}{l}\text { Debt sales } \\
\text { ratio(D/S })\end{array}$ & Total liabilities/Operating income $\times 100 \%$ \\
\hline & $\begin{array}{l}\text { Debt Asset } \\
\text { ratio(LEV) }\end{array}$ & total liabilities / total assets $\times 100 \%$ \\
\hline & Time(Year) & Annual dummy variable \\
\hline
\end{tabular}

\section{Descriptive statistics}

Table 2 is a descriptive statistical result of the variables in this paper.

Explanation of the median PC bit 0 , the mean is 0.0466 , the establishment of political connections between the firms, only $4.66 \%$ of China's private listed companies to establish a political connection.

Table 2 Descriptive statistics for each variable

\begin{tabular}{|c|c|c|c|c|c|c|c|c|}
\hline & $\mathrm{N}$ & Mean & Stad.Deviation & Minimum & $\begin{array}{c}\text { First } \\
\text { quartile }\end{array}$ & Median & $\begin{array}{c}\text { Third } \\
\text { quartile }\end{array}$ & Maximum \\
\hline PC & 5084 & .0466 & .2108 & .0000 & 0 & .0000 & 0 & 1.000 \\
\hline ROA & 5084 & .0524 & .0424 & -.2389 & 0.0256 & .0493 & 0.0740 & .482 \\
\hline ROE & 5084 & .0770 & .0643 & -.6341 & 0.0426 & .0730 & 0.1064 & .850 \\
\hline Province & 5084 & .9135 & .2812 & .0000 & 1 & 1.0000 & 1 & 1.000 \\
\hline Industry & 5084 & .8432 & .3636 & .0000 & 1 & 1.0000 & 1 & 1.000 \\
\hline Size & 5084 & 21.4390 & .8235 & 19.7557 & 20.8078 & 21.3400 & 21.9770 & 25.876 \\
\hline DS & 5084 & .7536 & 1.0074 & .0219 & 0.3151 & .5143 & 0.8620 & 26.877 \\
\hline LEV & 5084 & .3227 & .1865 & .0075 & .1714 & .3001 & .4527 & .953 \\
\hline
\end{tabular}

\section{The results of empirical research and its analysis}

\subsection{Multivariate regression statistical analysis}

Based on the previous theoretical analysis, according to the previous study and regression model, this paper carries out two-order least squares regression of three regression models. Table 3 reports the results of this multiple regression statistics. After OLS regression, the results of the three regression models were significant.

(1) shows that ROA is negatively correlated with PC but not significant, positively correlated with Province, but not significant, with PC * province at $10 \%$ level was positively correlated, indicating that the system environment is good in less government intervention areas, The establishment of a 
private firm, including government officials and representatives of the members of the political connection, the firm ROA will be a positive impacted.

(2) shows that ROE has a significant correlation with PC, and the coefficient is negative, which is significantly negatively correlated with Province, but ROE is positively correlated with PC * province at $1 \%$ level, indicating that politics is established in private firms the connections will significantly improve ROE in areas where the institutional environment is good and government intervention is low.

Table 3 (1-2) of the data shows that the theoretical analysis of the foregoing and the empirical results are basically the same, verify the hypothesis $1 \mathrm{~b}$, private firms to establish political connection, to pay a higher cost, Firms with no political connection are slightly lower, and political connections are negatively correlated with firm performance.

In addition, PC * Province was significantly correlated in the (1) to (2) columns at the significance levels of $10 \%, 1 \%$ and $5 \%$, respectively, and the coefficients were positive. Indicating that the institutional environment in the area where the firm is located can significantly affect the performance of the firms with political connections and bring economic benefits to the firms. Assume that 2 is supported.

Table 3 Relationship between political connection and firm performance

\begin{tabular}{|c|c|c|c|c|}
\hline & \multicolumn{2}{|c|}{ (1) $\mathrm{ROA}$} & \multicolumn{2}{|c|}{ (2) ROE } \\
\hline Variable & $\mathrm{t}$ & Sig. & $\mathrm{t}$ & Sig. \\
\hline Constant & 9.254 & .000 & 9.816 & .000 \\
\hline PC & -1.439 & .150 & -.451 & .652 \\
\hline Province & .280 & .779 & -3.361 & .001 \\
\hline PC*Province & 1.747 & .081 & 3.765 & .000 \\
\hline Industry & -7.247 & .000 & -8.042 & .000 \\
\hline Size & 15.917 & .000 & -4.596 & .000 \\
\hline $\mathrm{D} / \mathrm{S}$ & -11.420 & .000 & 16.543 & .000 \\
\hline LEV & -24.842 & .000 & -12.103 & .000 \\
\hline Year & \multicolumn{2}{|c|}{ Control } & \multicolumn{2}{|c|}{ Control } \\
\hline $\mathrm{N}$ & \multicolumn{2}{|c|}{5084} & \multicolumn{2}{|c|}{5084} \\
\hline Adjusted R2 & \multicolumn{2}{|c|}{.192} & \multicolumn{2}{|c|}{.094} \\
\hline Sig. & \multicolumn{2}{|c|}{.000} & \multicolumn{2}{|c|}{.000} \\
\hline $\mathrm{F}$ & \multicolumn{2}{|c|}{151.526} & \multicolumn{2}{|c|}{66.820} \\
\hline
\end{tabular}

\section{Conclusion}

Based on the research results of domestic and foreign scholars, this paper focuses on the relationship between the background of top managers and firm performance, takes the theory of rent - seeking and resource - dependence theory as the mainstay, and analyzes the theoretical part. The above results further show that the survival and development of firms need more resources, to occupy more markets, or in some rely on serious government survival, firms to establish, although for private firms to bring performance improvement. But the cost of building and maintaining the process, the impact on society and the market need to be taken seriously.

\section{Acknowledgments}

Fund projects: Education and scientific research project of middle and young teachers in Fujian (JAS160385); high level talent project of Xiamen University of Technology (YSK15010R).

Liu Lilong, 1981, female, Longyan Fujian, lecturer, Ph. D., engaged in the accounting research of government and non-profit organizations.

Guo Qianqian,1993, female, Xiamen Fujian, student of Xiamen University of Technology. 


\section{References}

[1] Ma Xiaowei, Su Zongqin, Zeng Yan, Xie Zhenzhu.A review of political association, corporate performance and corporate behavior[J]. Management Review,2010.

[2]Anup Agrawal, Charles R. Knoeber. Do Some Outside Directors Play a Political Role [J]. The Journal of Law and Economics, 2001.

[3]Buchanan J M. Rent Seeking and Profit Seeking”, in James M. Buchanan and others (eds), Towards a Theory of the Rent-Seeking Society[J]. 1980.

[4]Faccio B M. Politically-connected Firms: Can they squeeze the State[J]. 2010.

[5]Faccio M, Zingales L. Political Determinants of Competition in the Mobile Telecommunication Industry[J]. Social Science Electronic Publishing, 2017.

[6]Fisman R. Estimating the Value of Political Connections[J]. American Economic Review, 2001, 91(4):1095-1102.

[7]Lashitew A A. The Effect of Political Connections on Credit Access: Does the Level of Financial Development Matter [J]. Kyklos, 2014, 67(2):227-254.

[8]Rajan R G, Zingales L. Which Capitalism? Lessons from the East Asian Crisis[J]. 1998, 11(3):4048.

[9]Rijkers B, Baghdadi L, Raballand G. Political Connections and Tariff Evasion Evidence from Tunisia[J]. Policy Research Working Paper, 2015.

[10]Roberts B E. A Dead Senator Tells No Lies: Seniority and the Distribution of Federal Benefits[J]. American Journal of Political Science, 1990, 34(1):31-58. 